\title{
Effects of the different atmospheric steam curing processes on the properties of self-compacting-concrete containing microsilica
}

\author{
ABDULKADIR CÜNEYT AYDIN ${ }^{1, *}$, ALI ÖZ ${ }^{1}$, RIZA POLAT $^{1}$ and \\ HARUN MINDIVAN ${ }^{2}$ \\ ${ }^{1}$ Engineering Faculty, Civil Engineering Department, Atatürk University, \\ 25240 - Erzurum, Turkey \\ ${ }^{2}$ Engineering Faculty, Metallurgical and Materials Engineering Department, \\ Atatürk University, 25240 - Erzurum, Turkey \\ e-mail: acaydin@atauni.edu.tr
}

MS received 3 July 2014; revised 2 December 2014; accepted 8 December 2014

\begin{abstract}
In this paper an attempt has been made to study the use of microsilica on the properties of self-compacting-concrete (SCC) such as compressive strength, splitting tensile strength, flexural strength, ultrasonic pulse velocity (UPV) and microhardness when exposed to different atmospheric steam curing temperatures. The influence of microsilica as partial replacement of cement on the properties of SCC is investigated. In this study, mixes were prepared with three percentages of microsilica ranging from $5 \%$ to $10 \%$ and one controlled mixture without microsilica was also prepared for comparison. The specimens of each concrete mixture were heated up to different temperatures $\left(65^{\circ} \mathrm{C}, 70^{\circ} \mathrm{C}\right.$ and $\left.75^{\circ} \mathrm{C}\right)$. The variables included were the temperature effects $\left(65^{\circ} \mathrm{C}, 70^{\circ} \mathrm{C}\right.$ and $\left.75^{\circ} \mathrm{C}\right)$ using Cem I 42.5. SCC mixes enhanced atmospheric steam curing compressive strength ranging from 29.20 to $38.50 \mathrm{MPa}$, flexural strength ranging from 4.95 to $6.56 \mathrm{MPa}$ and splitting tensile strength ranging from 1.18 to $1.63 \mathrm{MPa}$. Test results clearly show that there is little improvement in the compressive strength within temperature range of $70^{\circ} \mathrm{C}$ as compared to 65 and $75^{\circ} \mathrm{C}$, although there is little reduction in splitting tensile strength ranging from 65 to $75^{\circ} \mathrm{C}$ and with the increase in percentage of microsilica. However, the rate of splitting tensile strength and flexural strength was higher than that of the compressive strength at elevated temperatures and with the increase in percentage of microsilica. In this paper, scanning electron microscopic (SEM) observations were also made to explain the observed residual compressive strength increase between $65^{\circ} \mathrm{C}, 70^{\circ} \mathrm{C}$ and $75^{\circ} \mathrm{C}$.
\end{abstract}

Keywords. Self-compacting concrete; UPV; strength; microsilica; microhardness.

*For correspondence 


\section{Introduction}

Use of self-compacting concretes (SCCs) lowered the noise level on the construction site and diminished the effect on the environment and has improved the quality of concrete in situ. SCC is a new category of high-performance concrete (HPC), which is characterized by its ability to spread into place under its own weight without the need of vibration and self-compact without any segregation and blocking. The introduction of SCC represents a major technological advance, which leads to a better quality of concrete produced and a faster and more economical concrete construction process. The use of SCC in civil engineering has gradually increased over the past few years. In addition, the increasing proportion of fine material is required and anything smaller than $0.125 \mathrm{~mm}$ should be considered as the fine grains of fine material. For this purpose, fly ash, stone dust (limestone powder), slag (ground) and silica fume can be used (Persson 2001; Xie et al 2015; Türkmen \& Kantarcı 2006; Sonebi 2004; Aydın 2007; Aydın \& Gül 2007; Bonavetti et al 2003; Bosiljkov 2003).

In order to accelerate the cement hydration reactions with saturated steam under atmospheric pressure is applied with heat. To increase concrete strength as well as temperature, the environment has to be saturated with enough moisture. Heat required to heat the media is achieved by steam curing. This process occurs under $100^{\circ} \mathrm{C}$ with atmospheric pressure, it is considered as a special case of humidity curing (Neville 1997).

Although maximum temperature limit values in curing locations should be from 40 to $100^{\circ} \mathrm{C}$, the temperature is applied between 65 and $80^{\circ} \mathrm{C}$. While the maximum temperature applied to the circuit of steam curing increases, the compressive strength of concrete will increase. The most effective and most important parameter on the degree of economic efficiency and successful application of steam curing is the steam curing cycle and cement type (Öztekin 1980).

In this study, normal aggregate was used to as aggregate. Three different atmospheric Steam Curing Cycles were applied to investigate the effect of microsilica on the properties of SCC. The cement type used was CEM I 42.5. The properties of SCC under the different atmospheric Steam Curing Cycles, i.e. the compressive strength and ultrasonic pulse velocity (UPV) were investigated. In addition to slump flow, V-Funnel and L box tests were performed to assess workability.

There are many studies related to the effect of mineral admixtures on the mechanical properties of SCC, although the effect of microsilica in the different atmospheric steam curing on the relationship between microhardness and compressive strength of SCC has not been reported previously. Therefore, the effects of pozzolanic activity of microsilica admixture on the mechanical properties of SCC also need to be investigated. Slump flow tests were performed to assess workability. Furthermore, the compressive strength, microhardness and UPV of hardened concretes are also determined for three different atmospheric steam curing cycles.

\section{Experimental program}

The chemical composition, physical and mechanical properties of the cement and microsilica used in this study are summarized in table 1. Furthermore, the microsilica is used as a replacement of total binder and proper for the standards ASTM C 618, ASTM C 1240/95, AASHTO M 307, and CAN/CSA23.5-M86.

The maximum size of coarse aggregates used was $16 \mathrm{~mm}$, while the smallest particles used as fine aggregate were $0-4 \mathrm{~mm}$. All the natural aggregates used for this study were in dry form. A polycarboxylic ether based high range water reducer (HRWR), density between 1.07 
Table 1. Chemical analysis and physical properties of Components.

\begin{tabular}{|c|c|c|}
\hline Component & CEM I $42.5(\%)$ & Microsilica (\%) \\
\hline $\mathrm{SiO}_{2}$ & 20.08 & 90.02 \\
\hline $\mathrm{Fe}_{2} \mathrm{O}_{3}$ & 6.01 & - \\
\hline $\mathrm{Al}_{2} \mathrm{O}_{3}$ & 2.05 & 0.3 \\
\hline $\mathrm{CaO}$ & 64.14 & 0.33 \\
\hline $\mathrm{MgO}$ & 0.93 & 2.36 \\
\hline $\mathrm{SO}_{3}$ & 0.74 & 0.85 \\
\hline Sulphide $\left(\mathrm{S}^{-2}\right)$ & 0.21 & - \\
\hline Chlor $\left(\mathrm{Cl}^{-}\right)$ & 0.0124 & - \\
\hline Undetermined & 0.32 & - \\
\hline Free $\mathrm{CaO}$ & 0.34 & - \\
\hline LOI & 1.55 & - \\
\hline Specific gravity $\left(\mathrm{g} / \mathrm{cm}^{3}\right)$ & 3.13 & 2.17 \\
\hline Specific surface $\left(\mathrm{cm}^{2} / \mathrm{g}\right)$ & 3751 & - \\
\hline Specific surface $(\mathrm{BET})\left(\mathrm{m}^{2} / \mathrm{kg}\right)$ & - & 20,000 \\
\hline \multirow[t]{3}{*}{ Compressive strength (MPa) } & 23.6 & \\
\hline & 37.9 & \\
\hline & 48.0 & \\
\hline
\end{tabular}

and $1.10 \mathrm{~g} / \mathrm{cm}^{3}$ (at $20^{\circ} \mathrm{C}$ ) was used to enhance the flow-ability of all the mixtures. Furthermore, the effect of SP percentage on the compressive strength is tested during pre-tests and its applicability observed by the insignificant compressive strength variation at the pre-test stage.

\section{Method}

In this study, three different atmospheric steam curing temperatures, namely $65^{\circ} \mathrm{C}, 70^{\circ} \mathrm{C}, 75^{\circ} \mathrm{C}$ and CEM I 42.5 as cement type were used. Therefore, a total of four different mixtures were cast in this study. The percentages of microsilica are decided according to the literature, sensitively. The full details of these mixtures are given in table 2. The self-compacting concrete mixtures were prepared in a laboratory mixer. The fine and coarse aggregate was initially dry mixed for approximately $30 \mathrm{~s}$. This was followed by the addition of cement, microsilica and $1 / 3$ of the total mixing water.

Table 2. Mixture proportions and fresh concrete properties of SCC mixes*.

\begin{tabular}{lcccccccccc}
\hline Mix & $\begin{array}{c}\text { Cement } \\
\left(\mathrm{kg} / \mathrm{m}^{3}\right)\end{array}$ & $\begin{array}{c}\text { Microsilica } \\
(\%)\end{array}$ & $\begin{array}{c}\text { FA } \\
\left(\mathrm{kg} / \mathrm{m}^{3}\right)\end{array}$ & $\begin{array}{c}\mathrm{CA} \\
\left(\mathrm{kg} / \mathrm{m}^{3}\right)\end{array}$ & w/b & $\mathrm{SP}(\%)$ & $\begin{array}{c}\text { Slump flow } \\
(\mathrm{mm})\end{array}$ & $\begin{array}{c}\text { U-box } \\
(\mathrm{mm})\end{array}$ & $\begin{array}{c}\text { L-box } \\
(\mathrm{mm})\end{array}$ & $\begin{array}{c}\text { V-Funnel } \\
(\mathrm{sn})\end{array}$ \\
\hline SCC1 & 400 & 0 & 1186 & 620 & 0.41 & 1.7 & 550 & 40 & 0.80 & 12 \\
SCC2 & 380 & 5 & 1181 & 617 & 0.42 & 1.8 & 700 & 20 & 0.90 & 9 \\
SCC3 & 370 & 7.5 & 1178 & 616 & 0.42 & 1.9 & 660 & 30 & 0.85 & 10 \\
SCC4 & 360 & 10 & 1168 & 611 & 0.44 & 2.0 & 680 & 30 & 0.90 & 11 \\
\hline
\end{tabular}

*FA stands for fine aggregates; CA for coarse aggregates; w/b for water-binder ratio; and SP for Super plasticizer). 
Table 3. Atmospheric steam cure cycles and characteristics.

\begin{tabular}{|c|c|c|c|c|c|c|c|c|c|}
\hline $\begin{array}{l}\text { Applied steam } \\
\text { cure cycles }\end{array}$ & \multicolumn{2}{|c|}{$\begin{array}{l}\text { Pre-pending } \\
\text { period }\end{array}$} & \multicolumn{2}{|c|}{ Heating period } & \multicolumn{2}{|c|}{$\begin{array}{l}\text { Heat impregnating } \\
\text { period }\end{array}$} & \multicolumn{2}{|c|}{ Cooling period } & $\begin{array}{l}\text { Total steam } \\
\text { cure cycle } \\
\text { Time (h) }\end{array}$ \\
\hline $65^{\circ} \mathrm{Ch} 24$ & 25 & 4 & $25-70$ & 4 & 70 & 24 & $70-32$ & 4.5 & $36 \mathrm{~h}$ \\
\hline $70^{\circ} \mathrm{C}$ & 27 & 4 & & 4 & 75 & 2 & & 4 & \\
\hline $75^{\circ} \mathrm{C} \mathrm{h} 24$ & 29 & 4 & $29-80$ & 4.5 & 80 & 24 & $80-32$ & 5 & $37 \mathrm{~h} 30 \mathrm{~min}$ \\
\hline
\end{tabular}

After 1.5 min of mixing, the rest of the mixing water together with the SP was added. The SP is used as a percentage of binder. All batches were mixed for a total mixing time of $5 \mathrm{~min}$. Specimens for the testing of the hardened properties were prepared by direct pouring of concrete into moulds without compaction. The self-compactability of the mixtures was examined according to standards of Self Compacting Concrete Committee of EFNARC (2002). For each mixture, nine samples of $100 \times 200 \mathrm{~mm}$ cylinders and three $70 \times 70 \times 280 \mathrm{~mm}$ prisms (totally 144 specimens) were prepared and the smooth finishes on the surfaces of $70 \times 70 \times 280 \mathrm{~mm}$ prisms without exposure of aggregates have been observed sensitively. The specimens have placed into the curing cabin with their moulds without delay after finishing of setting time for cement (190 min) and cured for $36.5 \mathrm{~h}$ in atmospheric steam cure at $65^{\circ} \mathrm{C}, 70^{\circ} \mathrm{C}$ and $75^{\circ} \mathrm{C}$. After curing period, the specimens are demoulded and stored till testing, for $24 \mathrm{~h}$ at $20 \pm 3^{\circ} \mathrm{C}$. The full details of these concrete mixes are given in table 2 . The atmospheric steam curing cycles and characteristics of mixes are presented in table 3 . At $36.5 \mathrm{~h}$, samples were tested for compressive strength, splitting-tensile strength and flexural strength (centre point loading) in accordance with ASTM C-192, ASTM C-496, and ASTM C-293, respectively. The atmospheric steam cure cycles and characteristics of mixes are presented in table 3.

Microhardness measurements were made using a Vickers microhardness tester. Measurements were obtained using a $0.01 \mathrm{~kg}$ test load and $10 \mathrm{~s}$ load duration. The first indentation was made $0 \mu \mathrm{m}$ from the aggregate surface with the long axis of the indenter parallel to the aggregate surface. Subsequent indentations were made in dimensions of every 15-20 $\mu \mathrm{m}$ (average) from the previous indentation and the whole analysis covered a distance from the aggregate surface of $150 \mu \mathrm{m}$ (Hussin \& Poole 2011).

\section{Results and discussion}

The data on the slump flow test of specimens made using normal aggregate and microsilica is given in table 2. As can be seen from table 2, concretes made with normal aggregate and containing microsilica show a flow diameter higher than $500 \mathrm{~mm}$. Thus, all concrete specimens are self-compacting concrete for shown slump flow diameter higher than $500 \mathrm{~mm}$. Flow diameter values changed up to 700, 680, 660 and $550 \mathrm{~mm}$ for SCC (see table 2). The controlled mixture without microsilica made with normal aggregate was reduced workability of concrete specimens. Khayat (1999a, b) reported that an SCC often contains high-volume replacements of fly ash or BFS to enhance fluidity and cohesiveness and limit heat generation. Such materials are generally less reactive than cement and can reduce problems resulting from the fluidity loss of rich concrete.

The behaviour of SCC and vibrated concrete differs significantly between $65^{\circ} \mathrm{C}$ and $75^{\circ} \mathrm{C}$. The compressive strength of concretes with or without microsilica at atmospheric steam curing to $65^{\circ} \mathrm{C}, 70^{\circ} \mathrm{C}$ and $75^{\circ} \mathrm{C}$ are shown in figure 1 . At atmospheric steam curing $65^{\circ} \mathrm{C}$ with the 


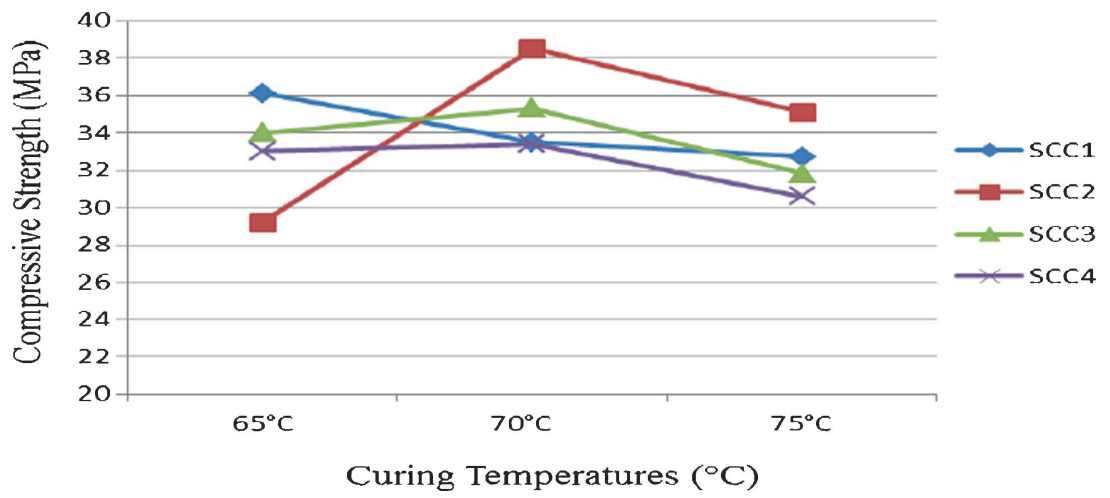

Figure 1. Relationship between compressive strength and curing temperatures.

increase in microsilica content from 5\% to 10\%, SCC mixes (SCC2-SCC4) developed compressive strengths between 34 and 29.2 MPa (table 4). Strength values were 36.1 MPa for the control mix (SCC1). An increase of strength was observed at atmospheric steam curing $65^{\circ} \mathrm{C}$ with the decrease of microsilica content from $10 \%$ to $5 \%$ (SCC4-SCC2) as compared with the control $\operatorname{mix}(\mathrm{SCC} 1)$.

At atmospheric steam curing $70^{\circ} \mathrm{C}$, SCC mixes (SCC2-SCC4) developed compressive strength ranged between 38.5 and $33.4 \mathrm{MPa}$. An increase of strength was observed at $70^{\circ} \mathrm{C}$, with the decrease of microsilica from $10 \%$ to $5 \%$ (SCC4-SCC2) as compared with the control mix (SCC1). At atmospheric steam curing $75^{\circ} \mathrm{C}$, SCC mixes (SCC2-SCC4) developed compressive strength ranged between 35.1 and $30.6 \mathrm{MPa}$. An increase of strength was observed at $75^{\circ} \mathrm{C}$, with the decrease of microsilica from $10 \%$ to $5 \%$ (SCC4-SCC2) as compared with the control mix (SCC1). The compressive strength increased with the decrease in microsilica content

Table 4. Hardened concrete properties.

\begin{tabular}{lccccc}
\hline & \multicolumn{5}{c}{ Samples } \\
\cline { 2 - 6 } Mixtures & $\begin{array}{c}\text { Compressive } \\
\text { strength (MPa) }\end{array}$ & $\begin{array}{c}\text { Flexure } \\
\text { strength (MPa) }\end{array}$ & $\begin{array}{c}\text { Splitting tensile } \\
\text { strength (MPa) }\end{array}$ & UPV (m/s) & $\begin{array}{c}\text { Dry unit weight } \\
\left(\mathrm{kg} / \mathrm{m}^{3}\right)\end{array}$ \\
\hline $\mathrm{SCC} 1$ & 36.1 & 5.5 & 1.3 & 4439 & 2350 \\
$65^{\circ} \mathrm{C}$ & 33.5 & 5.4 & 1.5 & 4570 & 2368 \\
$70^{\circ} \mathrm{C}$ & 32.7 & 6.5 & 1.3 & 4218 & 2380 \\
$75^{\circ} \mathrm{C}$ & & & & & \\
$\mathrm{SCC} 2$ & 29.2 & 6.6 & 1.6 & 4375 & 2355 \\
$65^{\circ} \mathrm{C}$ & 38.5 & 6.1 & 1.6 & 4623 & 2385 \\
$70^{\circ} \mathrm{C}$ & 35.1 & 7.4 & 1.3 & 4531 & 2332 \\
$75^{\circ} \mathrm{C}$ & & & & & \\
& 34.0 & 6.0 & 1.3 & 4525 & 2367 \\
$\mathrm{SCC} 3$ & 35.3 & 6.9 & 1.4 & 4705 & 2399 \\
$65^{\circ} \mathrm{C}$ & 31.8 & 6.0 & 1.4 & 4355 & \\
$70^{\circ} \mathrm{C}$ & & & & & 2372 \\
$75^{\circ} \mathrm{C}$ & 33.0 & 5.8 & 1.6 & 4591 & 2376 \\
$\mathrm{SCC} 4$ & 33.4 & 5.7 & 1.6 & 4624 & 2369 \\
$65^{\circ} \mathrm{C}$ & 30.6 & 5.0 & 1.2 & 4424 & \\
$70^{\circ} \mathrm{C}$ & & & &
\end{tabular}


and the water-to-cementitious materials ratio, as compared with the SCC mix prepared without microsilica. Strength loss of SCC mixes (SCC2-SCC4) at atmospheric steam curing of $65^{\circ} \mathrm{C}$ was approximately $1.95 \%$. Between 70 and $75^{\circ} \mathrm{C}$, there was slight reduction in strength. With further increase in temperature at $70^{\circ} \mathrm{C}$ there was little improvement in strength, as compared with SCC1.

Figure 3 shows the results obtained from the UPV measurements of all the SCC specimens subjected to different atmospheric steam curing. Each data point represents the average of three measurements. The schematic diagram of UPV measurement and the UPV-curing temperature results are shown in figures 2 and 3.

It is shown in figure 3 that the UPV of heated SCC specimens decreases with the increasing temperature, and there is a notable reduction in UPV shortly after the specimens are subjected to elevated temperature over $70^{\circ} \mathrm{C}$. It is obvious that the transmission of pulse waves through a concrete mass is highly influenced by the micro-cracking of concrete. Therefore, the decrease in pulse velocity with increasing temperature is a sensitive measure of the progress of cracking in the material. Yang et al (2009) also found similar results in their experiments.

The test results indicated that SCC mixtures were exposed to the atmospheric steam curing, $65^{\circ} \mathrm{C}$ and $75^{\circ} \mathrm{C}$ series showed higher reduction of pulse velocity when compared to $70^{\circ} \mathrm{C}$ series. Furthermore, it was noticed that the reduction of pulse velocity of SCC mixtures containing microsilica were significantly higher than those without microsilica in all replacement ratios. As can be seen from figure 2, pulse velocity had a continuous drop as the temperature was increased. It can be concluded that the addition of microsilica had a negative effect on the UPV of SCC mixtures exposed to atmospheric steam curing after $70^{\circ} \mathrm{C}$. In addition, thermal expansion and dehydration of the concrete due to high temperature might lead to the formation of fissures in the concrete. Because of more fissures, cracks or micro pathways in concrete pulse velocity delays to reach from the transmitter to the receiver (Yang et al 2009). Therefore, micro cracks cause the reduction of pulse velocity and results in low UPV values.

Microhardness testing is a powerful tool for characterizing the micro-structural properties of hardened cement paste (hcp) and interfacial transition zone (ITZ) (Igarashi \& Kawamura 1994). In this study, this testing method was applied to observe the influence of microsilica addition on the properties of bulk paste and the ITZ around aggregates. The ITZ is generally

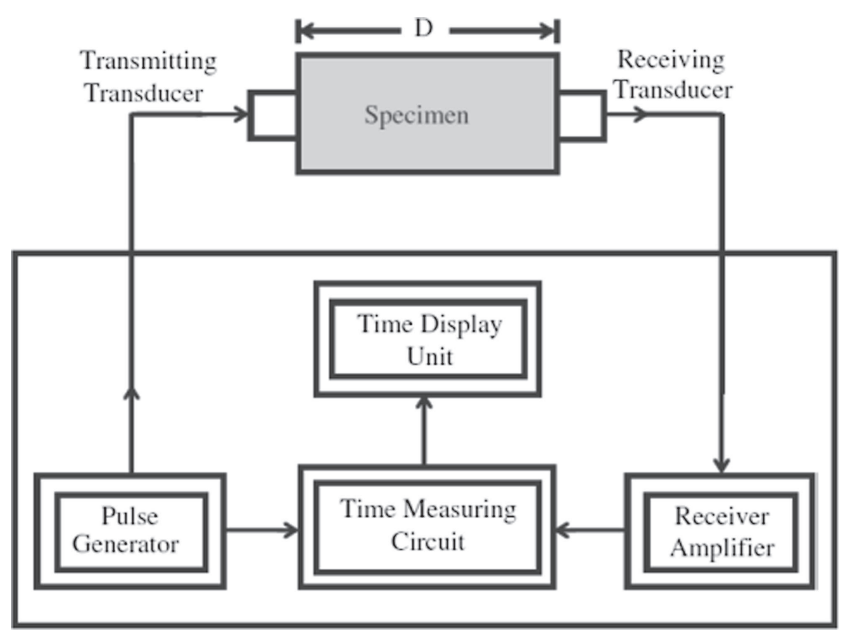

Figure 2. Schematic diagram of pulse velocity measurement. 


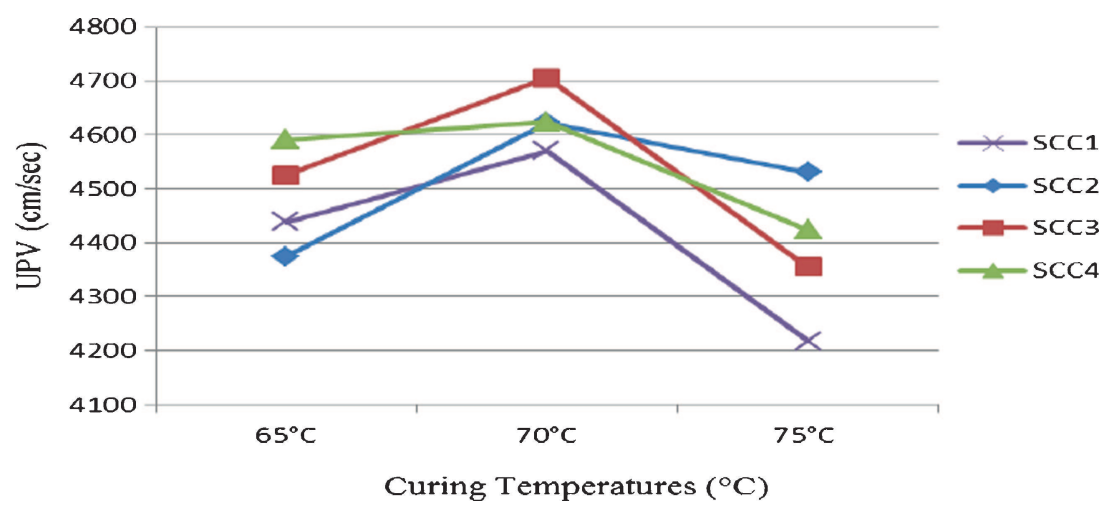

Figure 3. Relationship between UPV and curing temperatures.

accepted for less than $100 \mu \mathrm{m}$ in distance from aggregate surface, but the microhardness values are observed for above than $140 \mu \mathrm{m}$. Thus, the variation of microhardness through aggregate

(a)
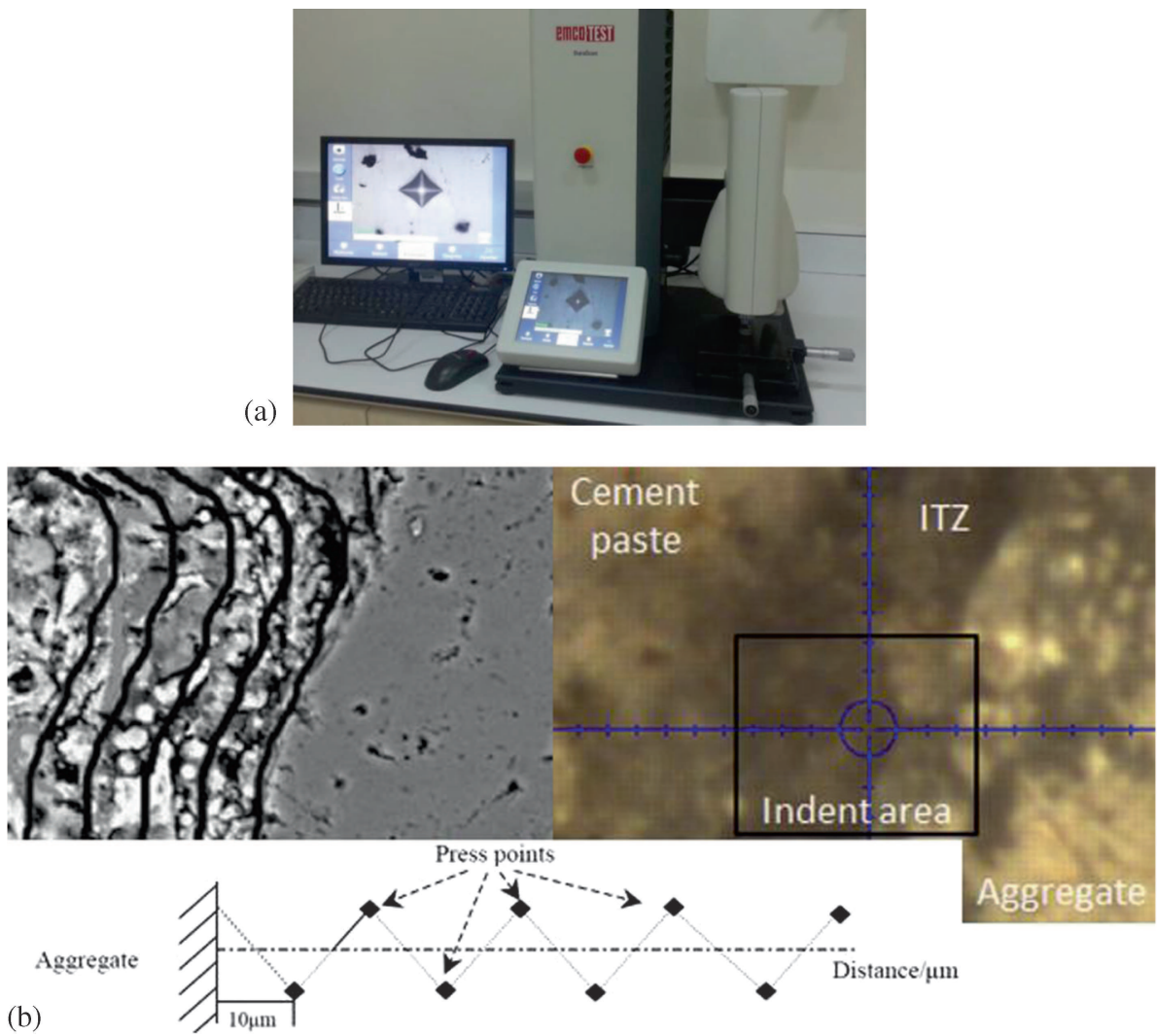

Figure 4. (a) Microhardness test setup. (b) Typical distribution points of microhardness measurements including image of intent area and strips moved successively starting from the surface of aggregate extending outward to bulk paste (Xie et al 2015; Duan et al 2013; Igarashi et al 1996). 
couldbe obtained. The reported microhardness values in the ITZ are results of concretes exposed to the atmospheric steam curing. Also reported is microhardness test data on bulk pastes in concretes exposed to the atmospheric steam curing. The microhardness test setup and typical distribution points of microhardness measurements including image of intent area and strips

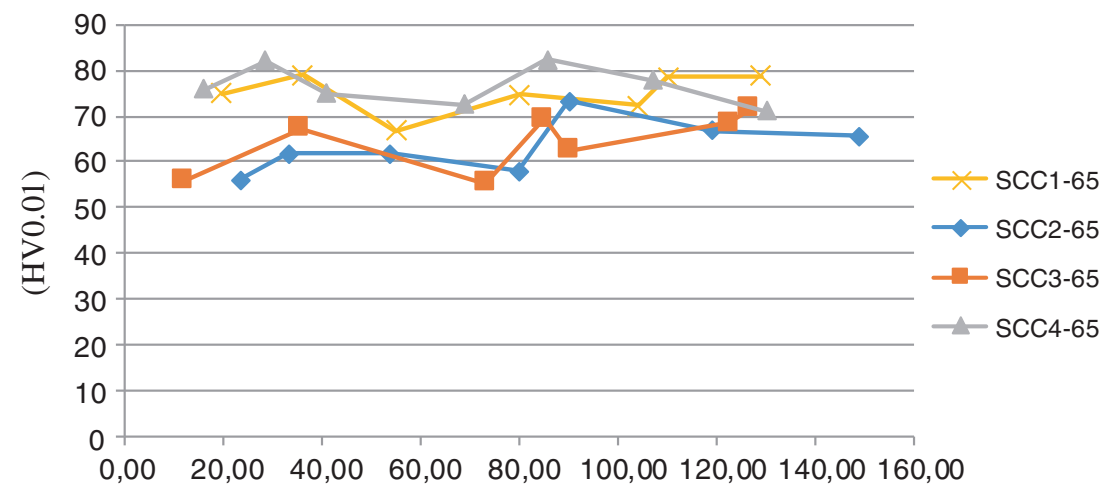

(a)

Distance from aggregate surface $(\mu \mathrm{m})$

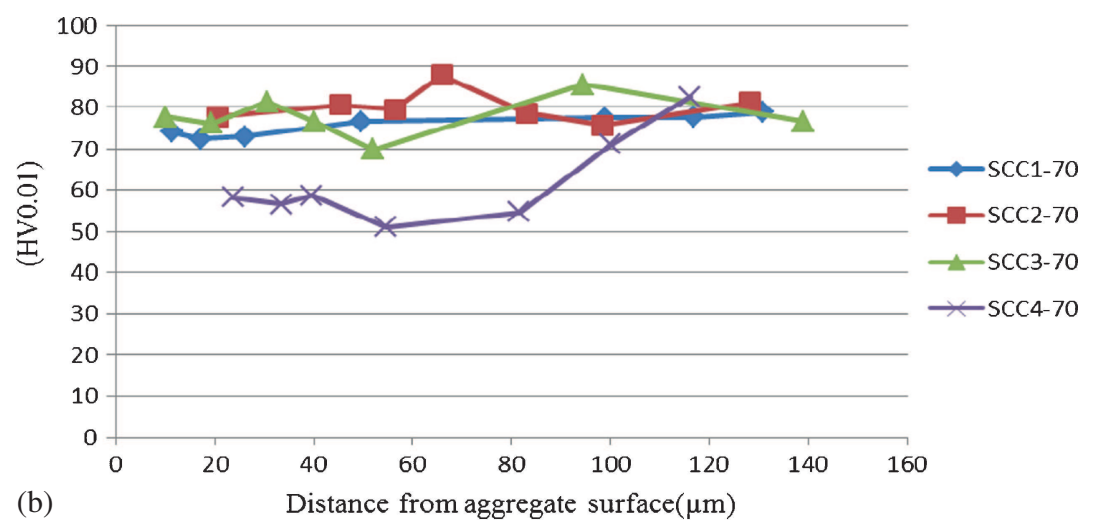

(b)

Distance from aggregate $\operatorname{surface}(\mu \mathrm{m})$

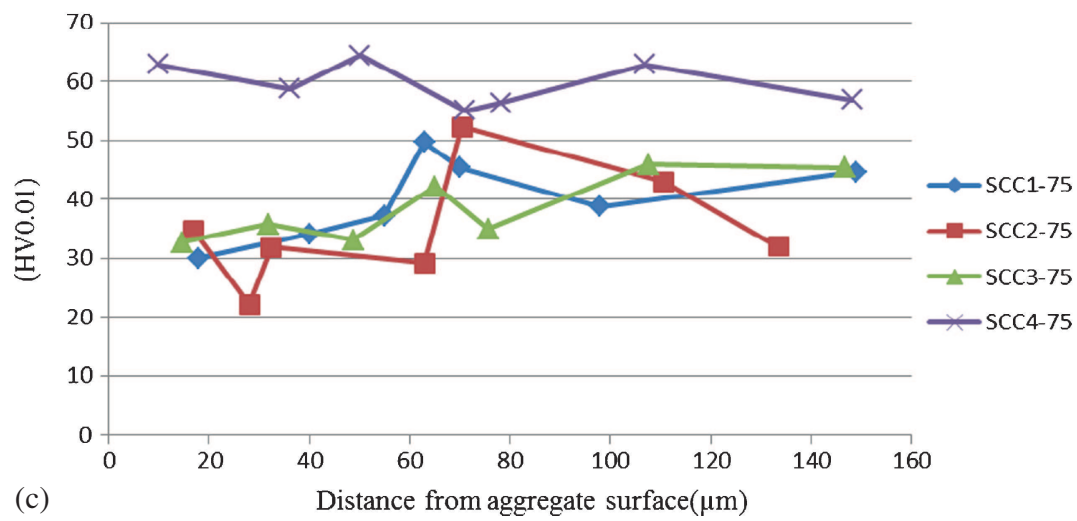

Figure 5. Vickers microhardness distribution in SCC containing microsilica after atmospheric steam curing (a) $65^{\circ} \mathrm{C}$, (b) $70^{\circ} \mathrm{C}$ and $(\mathbf{c}) 75^{\circ} \mathrm{C}$. 


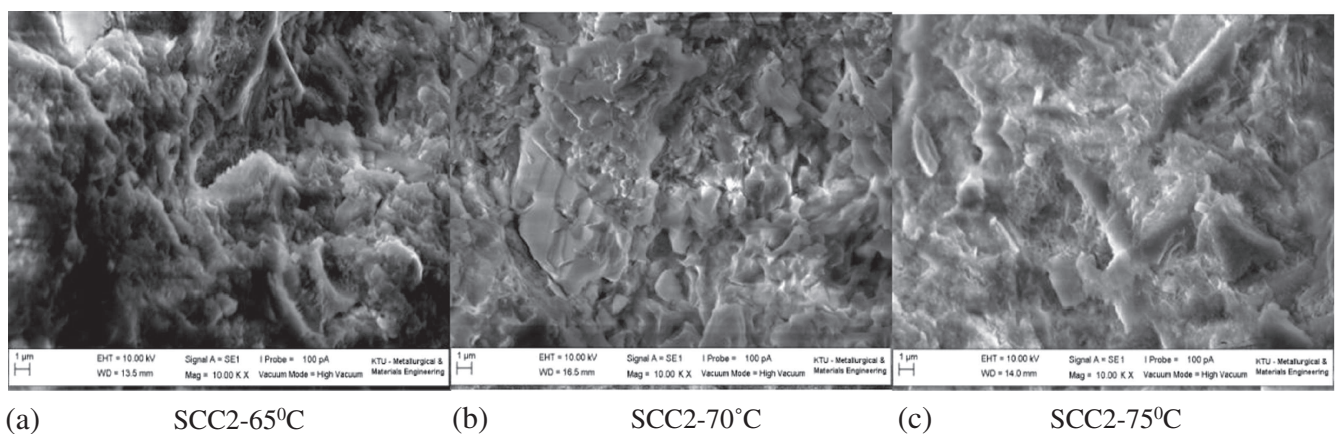

Figure 6. Aggregate-mortar ITZ modality in SCC containing microsilica as a partial replacement Portland cement $(\mathrm{Mag}=10.00 \mathrm{~K} \mathrm{X})$.

moved successively starting from the surface of aggregate extending outward to bulk paste (Xie et al 2015; Duan et al 2013; Igarashi et al 1996) are given in figure 4a and 4b.

Figure $5 \mathrm{a}-5 \mathrm{c}$ shows variation of ITZ ranges, i.e., where the microhardness test resulted in lower Vickers Hardness Numbers (Hv) than those in the middle of the hardened bulk cement pastes. It can be seen that the results display noticeable differences between the control mix and microsilica content. In the microsilica content concretes, within the ITZ region, the microhardness increases as the distance from the aggregate surface increases. No obvious increase in width of the weak zone (ITZ range) was observed when microsilica content was increased from 5 to $10 \%$. Increased microhardness values in the vicinity of the aggregate were observed in all specimens and this may be due to the presence of stiff inclusions in the excited range around the indentation, which restrains the flow of material under the indentation (Igarashi \& Kawamura 1994). These inclusions are the result of the significantly heterogeneous distribution of the hydration products in both the ITZ and bulk phase. Moreover, the porosity of the ITZ is generally higher than the bulk phase. Thus, hydration products and porous structure of ITZ results stiff inclusions.

Microhardness test results on bulk pastes are shown in figure $4 \mathrm{a}$ and $4 \mathrm{~b}$. The trend shows an increase in microhardness up to $65^{\circ} \mathrm{C}$ and $70^{\circ} \mathrm{C}$ and beyond $75^{\circ} \mathrm{C}$, microhardness decreases. The trend for microhardness variation is quite similar to that of compressive strength versus $\%$ of microsilica as shown in table 4.

The ITZ morphology of SCC examined in the SEM varies with the different specific surface area and the weight fraction of microsilica. Figure 6 presents the SEM pictures of aggregatemortar ITZ at the atmospheric steam curing. The study on SEM pattern of aggregation-mortar ITZ follows the regular results of the microhardness test. It is summarized as follows. At the same weight fraction of microsilica, the reaction products in the ITZ grow more compactly for the higher surface area material (compare figure 6a-6c). The ITZ shown in figure $6 \mathrm{c}$ appears to be denser than that in figure $6 \mathrm{a}$. It is apparent that microsilica at the weight fraction of $5 \%$ improves the ITZ microstructure the most.

\section{Conclusions}

This study concerns the behaviour of SCC at atmospheric steam curing. Specimens of various concretes compositions were made and subjected to different temperatures. The effects of atmospheric steam curing on the properties of SCC containing microsilica were studied. The 
compressive strength and splitting tensile strength, the reduction in UPV, microhardness and observation of surface characteristics of samples were investigated. Some conclusions can be drawn from the experimental results:

1. Although microsilica reduces the strength, it is still possible to produce SCC with adequate strength.

2. All the high volume microsilica concretes have satisfied the norms that were set to qualify them as SCC and fresh properties like workability were in good agreement with European guidelines. The developed SCC was highly segregation resistant and had good flow-ability and passing ability.

3. The SCC mixes developed compressive strengths ranging from 38.50 to 29.2 MPa. Splitting tensile strengths developed were from 1.18 to $1.63 \mathrm{MPa}$. The compressive strength increased with a decrease in the percentage of the microsilica and the water-to-cementitious materials ratio. Due to lower w/b ratio of control mixes, the compressive strength decrease could be contributed to lower performance of microsilica.

4. The UPV of heated SCC specimens decreased with the increasing temperature. Test results indicated that SCC mixtures were exposed to atmospheric steam curing, $65^{\circ} \mathrm{C}$ and $75^{\circ} \mathrm{C}$ series showed higher reduction of pulse velocity when compared to $70^{\circ} \mathrm{C}$ series. Furthermore, it was noticed that the reduction of the pulse velocity of SCC mixtures in which containing microsilica were significantly higher than without microsilica in all replacement ratios.

5. The trend shows an increase of microhardness up to $65^{\circ} \mathrm{C}$ and $70^{\circ} \mathrm{C}$ and beyond $75^{\circ} \mathrm{C}$, microhardness decreases. The trend for microhardness variation is similar to that of compressive strength versus $\%$ of microsilica as shown in table 4 .

6. It is apparent that microsilica at the weight fraction of 5\% improves the ITZ microstructure the most.

\section{References}

Aydin A C 2007 Self compactability of high volume hybrid fiber reinforced concrete. Constr. Build. Mater. 21: 1149-1154

Aydın A C and Gül R 2007 Influence of volcanic originated natural materials as additives on the setting time and some mechanical properties of concrete. Constr. Build. Mater. 21: 1274-1278

Aydın A C, Arslan A and Gül R 2007 Mesoscale simulation of cement based materials' time dependent behaviour. Comput. Mater. Sci. 41/1: 20-26

Bonavetti V, Donza H, Menééndez G, Cabrera O and Irassar E F 2003 Limestone filler cement in low w/c concrete: A rational use of energy. Cement Concrete Res. 33: 865-871

Bosiljkov V B 2003 SCC mixes with poorly graded aggregate and high volume of limestone filler. Cement Concrete Res. 33: 1279-1286

De Schutter G 2004 Guidelines for testing fresh self-compacting concrete. European Research Project, Testing SCC, Growth Contract No. GRD2-2000-30024, 2001-2004

Duan P, Shui Z, Chen W and Shen C 2013 Enhancing microstructure and durability of concrete from ground granulated blast furnace slag and metakaolin as cement replacement materials. J. Mater. Res. Technol. 2(1): 52-59

EFNARC 2002 Specification \& guidelines for self-compacting concrete. English edition. Norfolk, UK: European Federation for Specialist Construction Chemicals and Concrete Systems

Hussin A and Poole C 2011 Petrography evidence of the interfacial transition zone (ITZ) in the normal strength concrete containing granitic and limestone aggregates. Constr. Build. Mater. 25: 2298-2303

Igarashi S and Kawamura M 1994 Effects of a size in bundled fibers on the interfacial zone between the fibers and the cement paste matrix. Cement Concrete Res. 24(4): 695-703 
Igarashi S, Bentur A and Mindess S 1996 Microhardness testing of cementitious materials. Adv. Cement Based Mater. 4(2): 48-57

Khayat K H 1999a Workability, testing, and performance of self-consolidating concrete. ACI Mater. J.346353

Khayat K H 1999b Workability, testing, and performance of self-consolidating concrete. ACI Mater. J. 96: 346-354

Li V, Kong H J and Chan Y W 1998 Development of self-compacting engineered cementations composites. In: Proceedings, international workshop on self-compacting concrete, Kochi, Japan, 472-485

Nagataki S and Fujiwara H 1994 Self-compacting property of highly flowable concrete, Advances in Technology. Proceeding from the second CANMET/ACI international symposium, SP-154, V M Malhotra (ed.), American Concrete Institute, Farmington Hills, MI, 209-226

Neville A M 1997 Properties of concrete. 4th edition, London: Pitman Publishing Limited

Noumowe A, Aggoun S and Cabrillac R 2000 Mechanical properties of LWAC after exposure at high temperature. In: Second international symposium on structural lightweight aggregate concrete. 641-649

Okamura H and Ouchi M 2003 Self-compacting concrete. J. Adv. Concr. Technol. 1: 5-15

Öztekin E 1980 Beton Sertleşmesinin Hızlandırılmasında Isıl İşlem Çevrimi ve Çimento Seçimi, Tübitak Kurumu Bilgi Profili No 31, Ankara, Turkey

Persson B 2001 A comparison between mechanical properties of self-compacting concrete and the corresponding properties of normal concrete. Cement Concrete Res. USA 31: 193-198

Sahmaran M, Yurtseven A and Yaman I O 2005 Workability of hybrid fiber reinforced self-compacting concrete. Build Environ. 40: 1672-1677

Sonebi M 2004 Medium strength self-compacting concrete containing fly ash: Modelling using factorial experimental plans. Cement Concrete Res. 34: 1199-1208

Türkmen İ and Kantarc1 A 2006 Effect of expanded perlite aggregate and different curing conditions on the drying shrinkage of self-compacting concrete. Indian J. Eng. Mater. Sci. 13: 247-252

Xie Y, Corr D J, Jin F, Zhou H and Shah S P 2015 Experimental study of the interfacial transition zone (ITZ) of model rock-filled concrete (RFC). Cement Concrete Compos. 55: 223-231

Xie Y, Liu B, Yin J and Zhou S 2002 Optimum mix parameters of high strength self-compacting concrete with ultrapulvarized fly ash. Cement Concrete Res. 32: 477-480

Yang H, Lin Y, Hsiao C and Liu J Y 2009 Evaluating residual compressive strength of concrete at elevated temperatures using ultrasonic pulse velocity. Fire Safety J. 44: 121-130

Yuksel I, Siddique R and Ozkan O 2011 Influence of high temperature on the properties of concretes made with industrial by-products as fine aggregate replacement. Constr. Build. Mater. 25: 967-972 